\title{
Deliberate gait scissoring to overcome freezing of gait in Parkinson disease
}

Jorik Nonnekes, MD, PhD, and Bastiaan R. Bloem, MD, PhD

\author{
Correspondence \\ Dr. Nonnekes \\ jorik.nonnekes@ \\ radboudumc.nl
}

A 70-year-old man with Parkinson disease (PD) presented with gait scissoring, which he used purposely to overcome freezing of gait (video). This is important for 3 reasons. First, gait scissoring is traditionally equated with a functional disorder, but can apparently also be seen in PD. ${ }^{1}$ Second, although balance impairments are common in $\mathrm{PD}$, gait scissoring remains possible because patients have no mediolateral instabilities. ${ }^{2}$ Third, adopting a different walking pattern is a common strategy to reduce freezing (several other walking patterns have been described), presumably involving use of alternative motor programs that are less dependent on automatized gait generation by the basal ganglia. ${ }^{1}$

\section{Author contributions}

J.N. drafted the manuscript. B.B. collected video data and drafted the manuscript.

\section{Study funding}

No targeted funding reported.

\section{Disclosure}

The authors report no disclosures relevant to the manuscript. Go to Neurology.org/N for full disclosures.

\section{References}

1. Nonnekes J, Goselink RJM, Ruzicka E, Fasano A, Nutt JG, Bloem BR. Neurological disorders of gait, balance and posture: a sign-based approach. Nat Rev Neurol 2018;14:183-189.

2. Abdo WF, Borm GF, Munneke M, Verbeek MM, Esselink RA, Bloem BR. Ten steps to identify atypical parkinsonism. J Neurol Neurosurg Psychiatry 2006;77:1367-1369. 


\title{
Neurology
}

\author{
Deliberate gait scissoring to overcome freezing of gait in Parkinson disease \\ Jorik Nonnekes and Bastiaan R. Bloem \\ Neurology 2018;91;97 \\ DOI 10.1212/WNL.0000000000005780
}

This information is current as of July 9, 2018

\section{Updated Information \& Services}

\section{References}

Citations

Subspecialty Collections

Permissions \& Licensing

Reprints including high resolution figures, can be found at: http://n.neurology.org/content/91/2/97.full

This article cites 2 articles, 1 of which you can access for free at: http://n.neurology.org/content/91/2/97.full\#ref-list-1

This article has been cited by 1 HighWire-hosted articles: http://n.neurology.org/content/91/2/97.full\#\#otherarticles

This article, along with others on similar topics, appears in the following collection(s):

Gait disorders/ataxia

http://n.neurology.org/cgi/collection/gait_disorders_ataxia

Parkinson's disease/Parkinsonism

http://n.neurology.org/cgi/collection/parkinsons_disease_parkinsonism

Information about reproducing this article in parts (figures,tables) or in its entirety can be found online at:

http://www.neurology.org/about/about_the_journal\#permissions

Information about ordering reprints can be found online:

http://n.neurology.org/subscribers/advertise

Neurology ${ }^{\circledR}$ is the official journal of the American Academy of Neurology. Published continuously since 1951, it is now a weekly with 48 issues per year. Copyright @ 2018 American Academy of Neurology. All rights reserved. Print ISSN: 0028-3878. Online ISSN: 1526-632X.

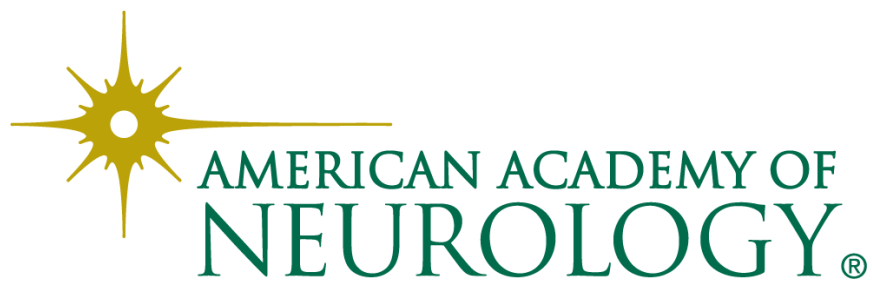

